軽金属 第 58 巻 第 11 号 (2008), 617-621

\title{
高強度・高勒性マグネシウム合金製長下肢装具の開発
}

\author{
金子 貫太郎 $*$ ・閤師 昭彦*・松田 靖史 $* *$ ·近藤 勝義 $* * *$
}

Journal of Japan Institute of Light Metals, Vol. 58, No. 11 (2008), pp. 617-621

\section{Development of knee ankle foot orthosis made of magnesium alloy with high strength and toughness}

\author{
Kantaro KANEKO*, Akihiko KOSHI*, Yasushi MATSUDA** and Katsuyoshi KONDOH***
}

Keywords: magnesium alloy, knee ankle foot orthosis (KAFO), lightweight, high strength, QOL (Quality Of Life)

\section{1. 緒言}

マグネシウム合金は実用金属では最軽量であるが，低強度 と成形加工の難しさゆえ，主に携帯電話やパソコンなどの筐 体に使用されているに過ぎない。著者らは，マグネシウム合 金の強度向上と成形加工性改善を目的に，独立行政法人新工 ネルギー・産業技術総合開発機構 (NEDO) · 大学発事業創出 実用化研究開発助成事業を平成 16 年度から 3 か年にわたり 実施した。その結果，開発した Roll-compaction（RCP）工法 を主要技術とした粉体プロセスを用いて，結晶粒微細化と集 合組織制御による高強度・高䩲性マグネシウム合金の創製に 成功した ${ }^{1), 2)}$ 。

本開発マグネシウム合金の用途展開として，軽量性が重視 される福祉用具を対象にその適用性を検討した。福祉用具の なかです，Fig. 1 に示す現行の両側金属支柱付き長下肢装具 （以下，両側支柱付 KAFO と略す）においては，障害者への 肉体的負担軽減の課題を有しており, 更なる軽量化・小型化
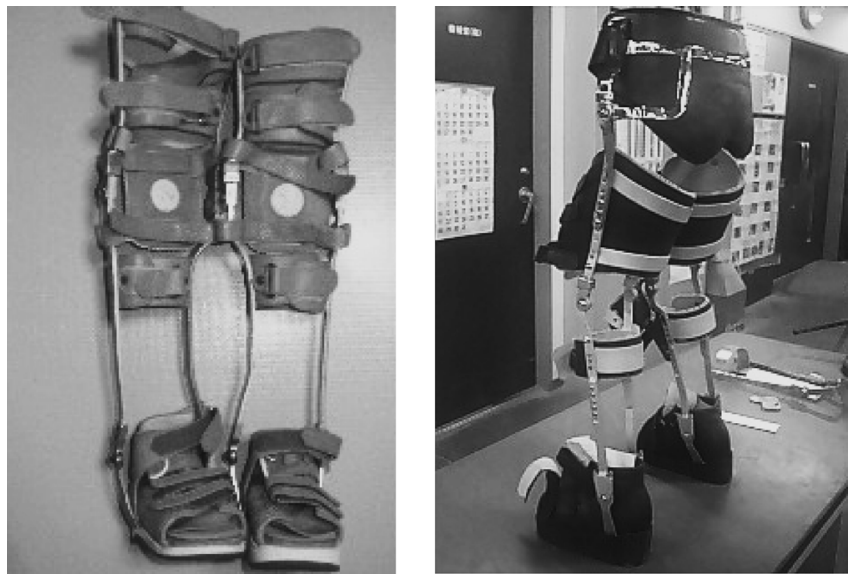

Fig. 1 Conventional double upright knee ankle foot orthosis (DU-KAFO).
が求められている。また，両側支柱付 $\mathrm{KAFO}$ はその外観・意 匠性において，利用者が必ずしも満足できるむのではない。 日常生活動作（以下，ADL と略す）の不便さの解消だけでな く, 意匠性を重視したデザインを付加することにより，利用 者が社会活動に参画しやすくなると考えられる。

そこで, 軽量化, ADL の不便さの解消および優れた意匠性 という特徵を持っ片側金属支柱付き長下肢装具（以下，片側 支柱付 KAFO と略す）を開発すべく, NEDO 福祉用具実用化 開発助成事業「良装用高強度・高勒性マグネシウム製軽量長 下肢装具の開発」を平成 19 20 年度において実施した。本報 では，平成 19 年度に作製した片側支柱付 KAFO の特性につ いて報告する。

\section{2. 現行の両側支柱付 KAFO の構造}

両側支柱付 KAFO の骨組み構造を Fig. 2 に示す。支柱

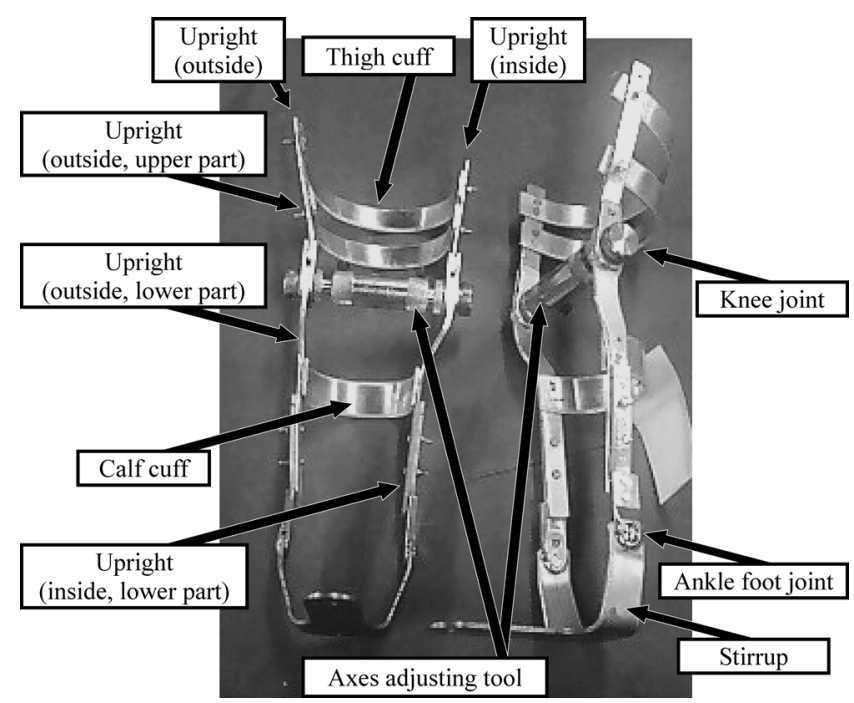

Fig. 2 Metal flame of DU-KAFO.

* 株式会社栗本鐵工所（一 550-8580 大阪府大阪市西区北堀江 1-12-19)。Kurimoto, Ltd.（1-12-19 Kitahorie, Nishi-ku, Osaka 550-8580). E-mail:k_kaneko@kurimoto.co.jp

**⿻川村義肢株式会社（大東市)。Kawamura Gishi Co., Ltd.（Daito-shi, Osaka）

***大阪大学接合科学研究所（茨木市)。Joining and Welding Research Institute, Osaka University (Ibaraki-shi, Osaka). 受付日：平成 20 年 5 月 2 日 受理日：平成 20 年 8 月 21 日 
（Upright）は外側，内側抢よび上部，下部に分けられる。 上・下部支柱は脚の外側と内側に沿って取付けられ, 膝継手 （Knee joint）で接続されている。また，上・下部支柱の外側 部分と内側部分はそれぞれ大腿半月（Thigh cuff）と下腿半 月 (Calf cuff) で繫ぎ一体化する。調整工具 (Axes adjusting tool）にて外・内側支柱の膝継手の軸芯を調整後, 調整工具 を外す。歩行時は膝を伸ばして，手で膝継手をロック状態に することにより，支柱は真直ぐ固定され体重を支える。着座 時はロックを開放すると, 膝継手部で上・下部支柱が約 $90^{\circ}$ 折れて座ることができる。下部支柱の下端部にはあぶみ （Stirrup）が足継手（Ankle foot joint）で接続されている。足 継手は歩きやすいょうに，角度を前後 $15^{\circ}$ 以内で自由に調整 できる。利用者は履いた靴をあぶみの上に載せて，大腿部の 後側を大腿半月に当て前側をバンドで締めて固定する。ふく らはぎ部も同様に後側を下腿半月に当て，バンドで固定する。

\section{3. 開発の課題}

\section{1 両側支柱付 KAFO の問題点}

現在使用されている両側支柱付 KAFO は，次の上うな問題 点がある。

(1) 重さ

支柱に使用される各種合金の比重を Fig. 3 に示す。多くの 支柱は比重が大きい構造用鋼またはステンレス鋼で製作して いる。子供などが使う支柱，半月およびあぶみなどはアルミ ニウム合金を使用する。チタン合金とマグネシウム合金を用 いたあのもあるが，高価または強度不足のため現時点での使 用率は極めて少ない。その中でアルミニウム合金を使用する 両側支柱付 KAFO に扔いても足部覆いの付いた KAFO の重量 が約 $3.5 \mathrm{~kg}$ であり，高齢者や重い身体障害を持つ利用者に とっては負担が大きい。そのため利用者が疲れやすくなり, また行動範囲も狭くなる。

（2）構造による ADL の不便さ

内側の支柱が，内旋足（内股歩き）での歩行になりがちな 脳性麻痺障害者にとっては，歩行時の妨げになる。また，内 股部品や坐骨支持部材は Fig. 4 に示すように取付けられてい るので，用便時の脱衣と着衣の大きな妨げとなり，急な尿 意・便意が生じた際のもどかしさ・切実感は利用者にとって 精神面・衛生面に打いて大きな負担となる。

(3) 構造に起因する長い納期

最近の研究では, 脳卒中片麻痺に対して下肢装具を早期か ら用いて積極的にリハビリテーション（以後，リハビリ）を施 しておくことが，リハビリ効果を高めると報告されている3 ${ }^{3}$ 。 しかしながら，人間の膝関節は単純な一軸構造ではなく，転 がり軸受と滑り軸受の合成である生理軸であるため, 両側支 柱付 KAFO では Fig. 2 に示すように，仮想軸を探りながら左 右の軸を工具で同軸にする調整作業が必要となる。この調整 作業に手間之時間がかかるため, 義肢装具士と義肢装具製作 技能士には大きな負担となっている。このため, 納期が 1 2 週間と長くなり，早期りハビリ開始に支障が生じる。

（4）外観之意匠性

現行の両側支柱付 KAFO は，その外観や意匠性が利用者に とって受け入れにくいことも大きな問題である。

\section{2 開発課題}

上記問題点から次の課題が設定される。

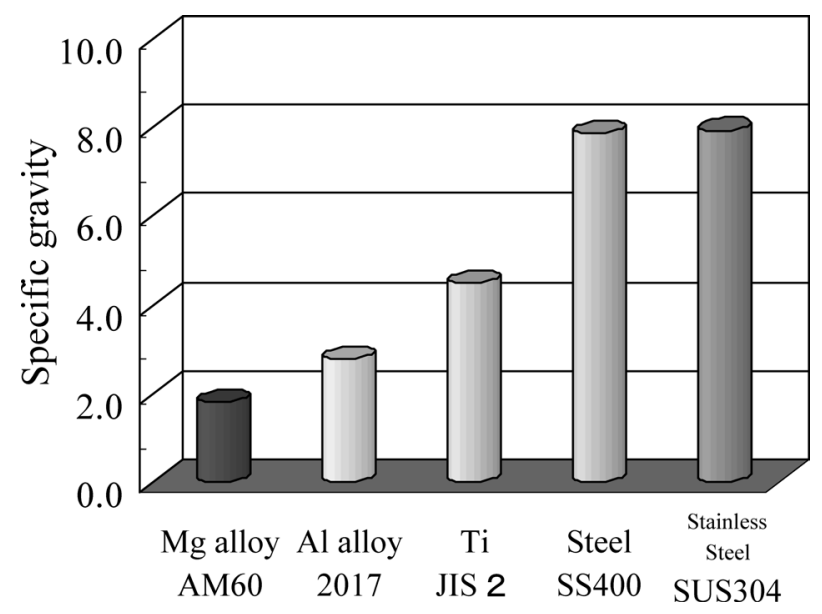

Fig. 3 Specific gravity of various alloys for KAFO.

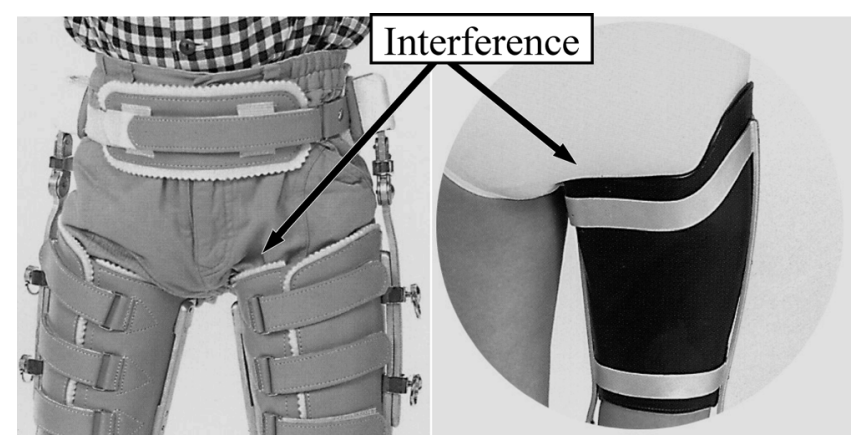

Fig. 4 Interference with groin, ischium, and KAFO.

（1）軽量化

強度と延性に優れたマグネシウム合金を使用すること

により KAFO の軽量化を実現する。

（2）構造改良

$\mathrm{ADL}$ を容易にするため，内側の支柱をなくし，支柱は 外側のみの構造とする。また, 部品の標準化により製作 の短納期化を図る。

（3）意匠性の向上

利用者が社会活動に参画しやすい，優れた意匠性を持 つデザインを行う。

\section{4. 高強度・高勒性マグネシウム合金を用いた片側 支柱付 KAFO}

\section{1 マグネシウム合金の高強度化}

$\mathrm{KAFO}$ の軽量化には，高強度マグネシウム合金を使用する ことが最あ有効であると思われる。しかしながら，汎用マグ ネシウム合金はアルミニウム合金に比べて強度が低いため, マグネシウム合金の高強度化が必要である。

本開発ではマグネシウム合金の高強度化のために，前述の RCP 工法を利用した。準量産設備である RCP-200 の外観写真 を Fig. 5 に示す。また, マグネシウム合金粉末原料から RCP 工法を経て, 押出・鍛造工程までの全工程の製造プロセス模 式図を Fig. 6 に示す。出発原料は, 独立行政法人産業技術 総合研究所が製造技術を確立した難燃性マグネシウム合金 AMX602を採用した。Fig. 7 に示すようにマグネシウム合金 に 1 2 mass\% のカルシウムを添加すると, 燃焼開始温度が 200 $300^{\circ} \mathrm{C}$ 高くなり, 800 $900^{\circ} \mathrm{C}$ でも爆発的に燃焼しない ${ }^{4)}$ 。 


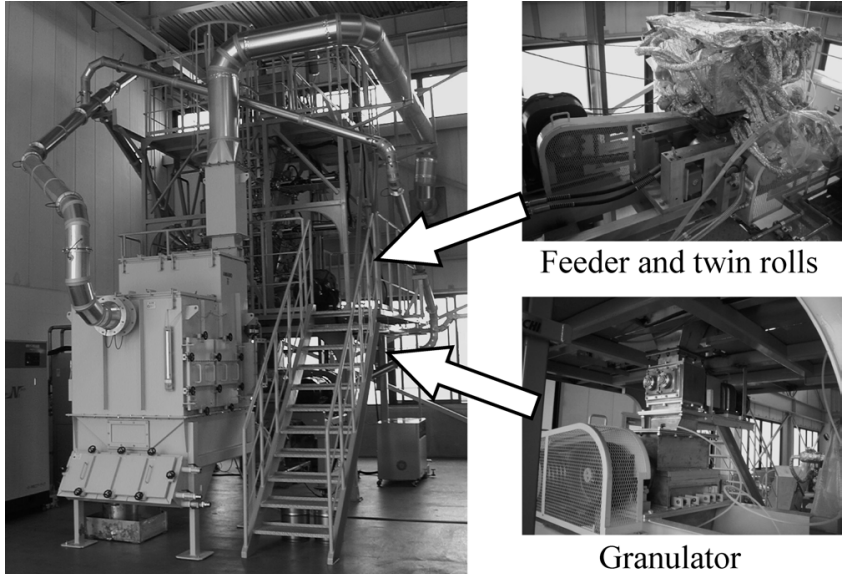

Fig. 5 RCP system for semi-mass production of magnesium alloy.

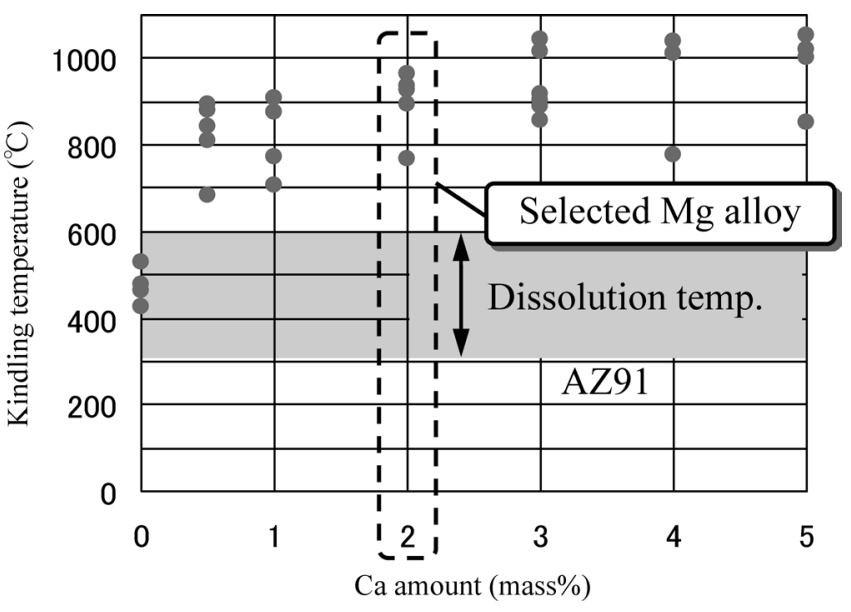

Fig. 7 Relation between Ca amount and flame resistance of magnesium alloys.
Mg raw powder

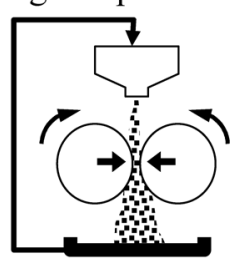

RCP system

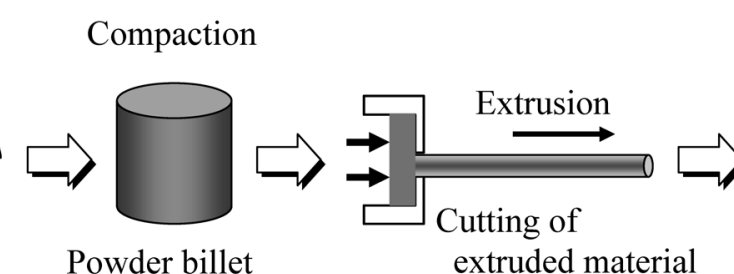

Powder billet

extruded material
Hot forging

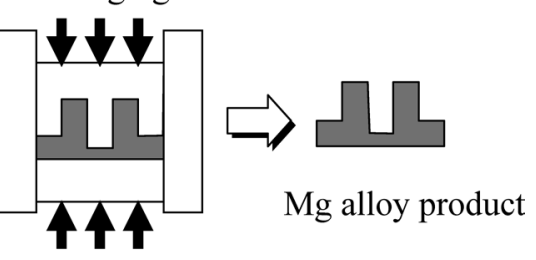

Fig. 6 Total manufacturing process from RCPed powder production through forging.

(a) Raw powder

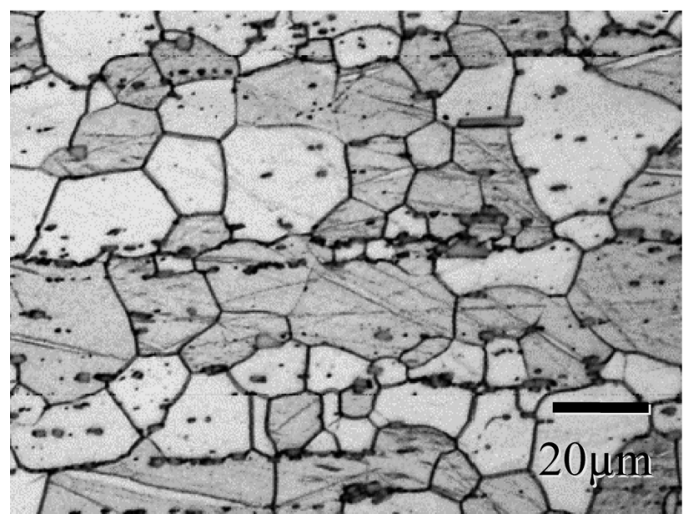

(b) RCPed powder

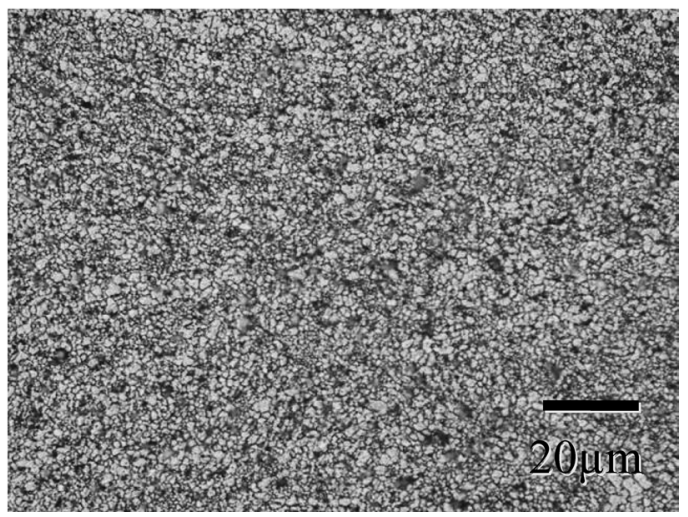

Fig. 8 Optical microstructures of hot extruded AMX602 alloy in using raw powder (a) and RCPed one (b).

AMX602 鋳造ビレットを用いて作製した押出材の結晶粒径は Fig. 8 (a) に示すように数 $30 \mu \mathrm{m}$ であるが， RCP 工法処理 (50 パス処理) を施した同一組成粉末からの押出材の結晶粒 は Fig. 8 （b）に見られるように，押出加工過程における動的 再結晶により平均粒径 $1.2 \mu \mathrm{m}$ と鋳造ビレット押出材の $1 / 10$ 以下となった。その結果, Fig. 9 に示すように従来のマグネ シウム合金押出材と比べて約 2 倍の高い強度を有し，さらに アルミニウム合金 6061-T6 熱処理材を超える強度特性を持つ 高強度・高勒性マグネシウム合金部材を製造することができ た。ちなみに, 上記の RCP 工法による高強度化プロセスで は，取扱うマグネシウム粉体が数ミリ単位と大きいため，粉 塵爆発の危険がない。また，AMX602 を使用しているため， 支柱, 半月およびあぶみなどの切断・研磨時に発生する微粉
についても発火等の危険性が少ない。本開発の KAFO には難 燃性マグネシウム合金を用いているが，他の組成の合金に対 しても，上記のプロセスによる高強度化が可能であることを 付記する。

\section{2 高強度 $A M X 602$ を用いた片側支柱付 KAFO}

(1) 軽量性

開発した KAFO を Fig. 10 に示す。支柱は外側のみとして 内側をなくした。また, 支柱, 半月およびあぶみは高強度 AMX602 で作製した。支柱とあぶみは特殊形状の中空断面構 造とした。開発した片側支柱付 KAFO の強度を確認するため に, 健常者が装着して官能試験を行ったところ, 結果が良好 であった。なお，今回の試作品における膝継手と足継手には， その機能確認が目的であったためアルミニウム合金，黄銅お 
よび構造用鋼を用いたが，今後は RCP 工法を適用した高強度 AMX602 等を適用していく。

（2）耐食性

高強度 AMX602 と両側支柱付 KAFO に多く使用されてい るアルミニウム合金 A2024-T4 の塩水噴霧と人工汗による腐 食試験の結果を Fig. 11 に示す。A2024-T4 試験片には表面処 理を施さない押出材を使用し，AMX602 試験片においては表 面処理を施さない押出材と陽極酸化処理した押出材の両方を

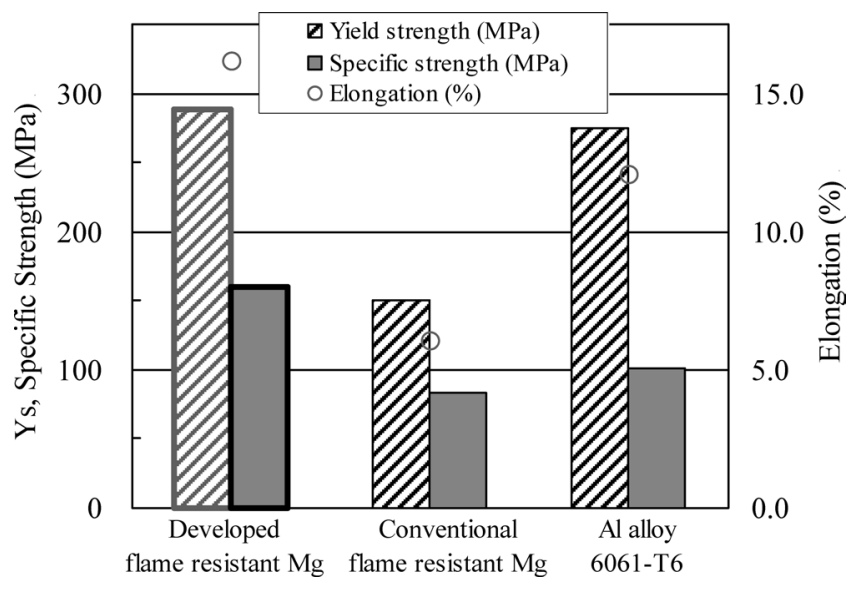

Fig. 9 Yield strength of various light metal.
使用した。すべての試験片表面にはナイフでクロスカットし， 陽極酸化処理した試験片表面のクロスカットは素地まで達し た。塩水噴霧試験は JISZ2371 に基づいて行い, 試験時間は

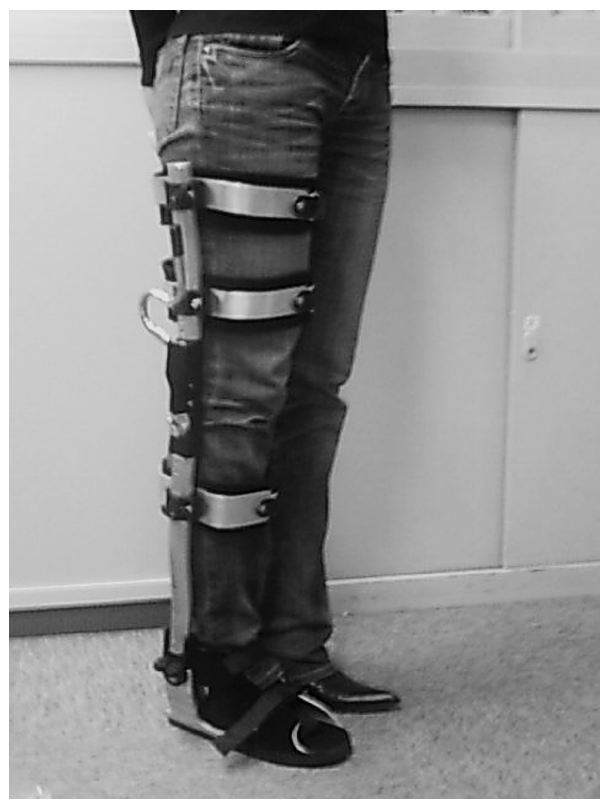

Fig. 10 Single upright KAFO made of RCPed magnesium alloy (2007 model).

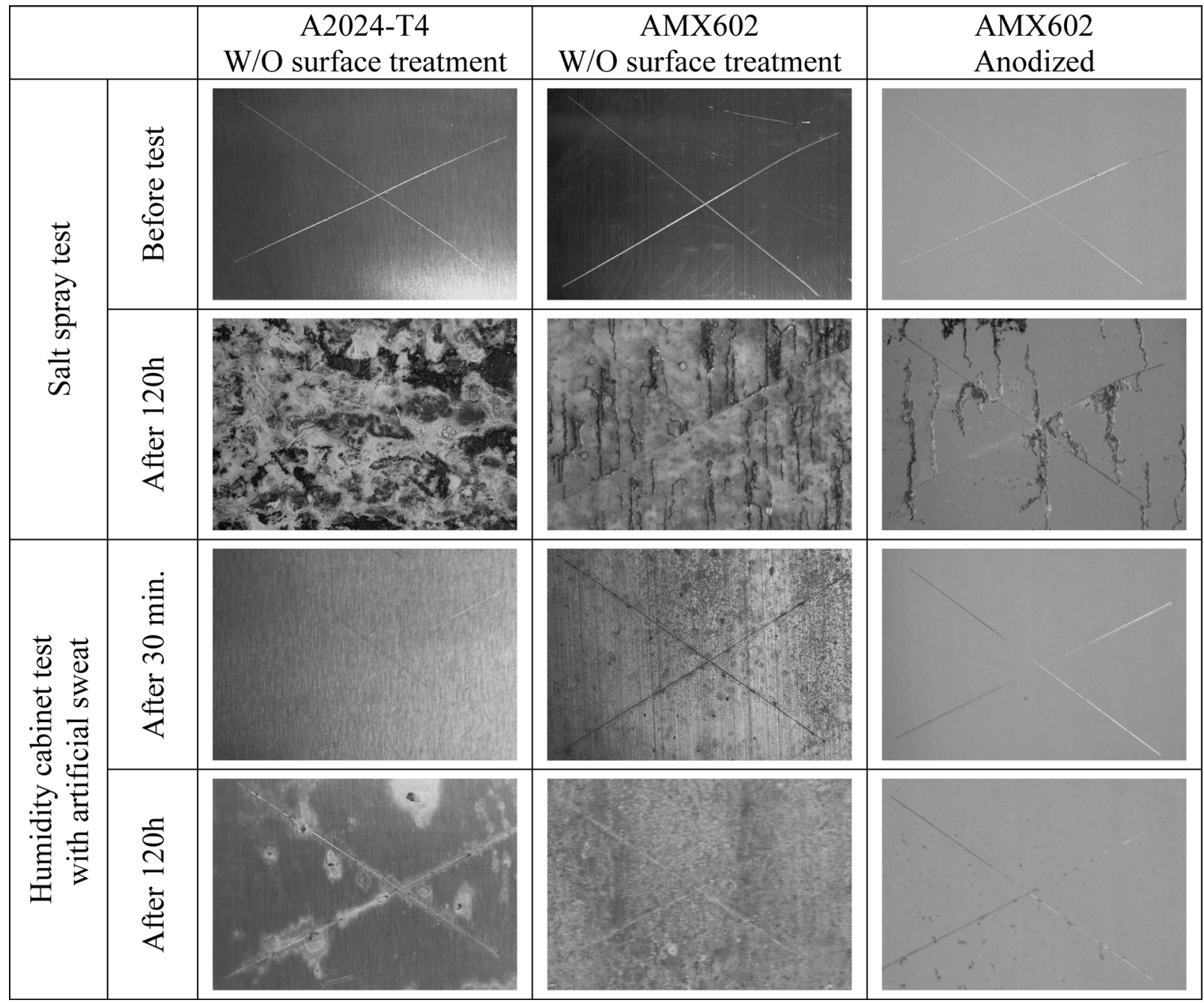

Fig. 11 Corrosion test results. 
120 時間とした。試験後に A2024-T4 は表面に全面腐食が発生 した。AMX602 は 2 種類とも糸状錆腐食が発生したが，腐食 の程度は A2024-T4 より軽く, 特に陽極酸化処理を施した試 験片はさらに腐食損傷が少ないことを確認した。

人工汗腐食試験に使用した酸性人工汗試験液は, JISL0848 に基づくものである。人工汗を霧吹きで試験片に吹付けた後, $40^{\circ} \mathrm{C}$ で湿度 $90 \% \mathrm{RH}$ の雾囲気内に試験片を 120 時間放置した。 30 分後には表面処理しない AMX602 は变色し, 糸状錆腐食 が発生したが，他の 2 種類の試験片表面には腐食が認められ なかった。120 時間後には, すべての試験片表面に腐食が発 生・進行したが, 腐食程度は表面処理しないAMX602, A2024-T4, 陽極酸化処理 AMX602 の順で軽減し, 陽極酸化 処理した AMX602 は腐食損傷量が最も軽微であった。

上記の結果から陽極酸化処理した AMX602 はA2024-T4 と 同等またはそれ以上の耐食性を有することが確認できた。

（3）その他

(1) 軽量性

高強度 AMX602 を用いることにより, 従来のアルミニウ ム合金製両側支柱付 KAFO を軽量化することができる。

(2) 短納期

膝継手のワンタッチロック機構と足継手の角度調整機構 には，現行の両側支柱付 KAFO と同じ機能を持たせた。膝 継手と足継手が各 1 個となったので，両側支柱付 KAFO の ような煩わしかった左右の両軸調整作業は不要となった。 また, 支柱, 半月, あぶみ, 膝継手および足継手等の主要 構成部品は標準化して在庫を持つとともに, 利用者に合わ せる調整作業を脚のサイズに対する支柱の長さと半月の曲 率だけの最小限にすることで, 納期を $2 \sim 3$ 日にする目途が ついた。

(3) 意匠性と装脱着の負荷低減

片側支柱付きとしたため, 意匠性は大幅に改善でき,
ADL 屯容易になったと考えている。また，この構造は，装 着は体側部から行えるので, 現行の両側支柱付 $\mathrm{KAFO}$ と比 較して介護者の肉体的負担と手間を大幅に軽減できるとと もに，利用者にも装脱着の負担が軽減されるという効果も あった。

\section{5. おわりに}

上記のとおり, RCP 工法を施した高強度・高勒性マグネシ ウム合金 AMX602 を支柱, 半月およびあぶみに適用し, 片側 支柱付 KAFO を開発した。塩水噴霧試験と人工汗腐食試験 によりその耐食性を確認するとともに，健常者による官能試 験で開発した片側支柱付 KAFO の実用性を検証した。また， この片側支柱付 KAFO は現行の両側支柱付 KAFO に比べて 納期，意匠性等も改善された。

今後は, 支柱, 半月およびあぶみの最適形状化を図るとと あに，高強度 AMX602 を膝継手と足継手に適用することによ りさらなる軽量化を行う。また，利用者によるモニタリング 結果を反映して, 操作性と意匠性の改善を行い, 快適な $\mathrm{ADL}$ を保障する片側支柱付 KAFO の完成を目指す。

最後に, 本研究開発助成事業の遂行に際してご支援頂いた NEDO ならびに試作品の完成までに多大な協力を頂いた関係 者各位に謝意を表する。

\section{参 考 文 献}

1）金子貫太郎, 塩崎修司, 護法良憲, 秋田 亨, 近藤勝義, 荻沼 秀樹：塑性と加工, 47 (2006), 49-52.

2）金子貫太郎，塩崎修司，近藤勝義，荻沼秀樹，秋田 亨：まて りあ, 45 (2006), 54-56.

3）藤本幹夫：日本義肢装具学会誌, Vol. 22 特別号（2006）, 146147

4）侏ケーエステクノス・カタログ：マグネシウムの難燃化技術よ り「Ca 添加量と発火温度の関係」. 